\title{
QUEEN'S
UNIVERSITY
BELFAST
}

\section{Human resource management practices in the multinational company: A test of system, societal, and dominance effects}

Edwards, P. K., Sánchez-Mangas, R., Tregaskis, O., Lévesque, C., McDonnell, A., \& Quintanilla, J. (2013).

Human resource management practices in the multinational company: A test of system, societal, and dominance effects. Industrial and Labor Relations Review, 66(3), 588-617.

$\mathrm{http}: / /$ ilr.sagepub.com/search/results?fulltext=Human+resource+management+practices+in+the+multinational+c ompany $\% 3 A+A+$ test+of+system $\% 2 C+$ societal\% $2 C+$ and+dominance+effects\& $x=0 \& y=0 \&$ submit=yes\&journal_set $=$ spilr\&src=selected\&andorexactfulltext=and

Published in:

Industrial and Labor Relations Review

Document Version:

Publisher's PDF, also known as Version of record

Queen's University Belfast - Research Portal:

Link to publication record in Queen's University Belfast Research Portal

Publisher rights

(C) Cornell University

\section{General rights}

Copyright for the publications made accessible via the Queen's University Belfast Research Portal is retained by the author(s) and / or other copyright owners and it is a condition of accessing these publications that users recognise and abide by the legal requirements associated with these rights.

Take down policy

The Research Portal is Queen's institutional repository that provides access to Queen's research output. Every effort has been made to ensure that content in the Research Portal does not infringe any person's rights, or applicable UK laws. If you discover content in the Research Portal that you believe breaches copyright or violates any law, please contact openaccess@qub.ac.uk. 


\title{
HUMAN RESOURCE MANAGEMENT PRACTICES IN THE MULTINATIONAL COMPANY: A TEST OF SYSTEM, SOCIETAL, AND DOMINANCE EFFECTS
}

\author{
PAUL K. EDWARDS, ROCÍO SÁNCHEZ-MANGAS, \\ OLGA TREGASKIS, CHRISTIAN LÉVESQUE, \\ ANTHONY MCDONNELL, AND JAVIER QUINTANILLA*
}

\begin{abstract}
Does the use of HRM practices by multinational companies (MNCs) reflect their national origins or are practices similar regardless of context? To the extent that practices are similar, is there any evidence of global best standards? The authors use the system, societal, and dominance framework to address these questions through analysis of 1,100 MNC subsidiaries in Canada, Ireland, Spain, and the United Kingdom. They argue that this framework offers a richer account than alternatives such as varieties of capitalism. The study moves beyond previous research by differentiating between system effects at the global level and dominance effects arising from the diffusion of practices from a dominant economy. It shows that both effects are present, as are some differences at the societal level. Results suggest that MNCs configure their HRM practices in response to all three forces rather than to some uniform global best practices or to their national institutional contexts.
\end{abstract}

\footnotetext{
*Paul Edwards is Professor of Employment Relations at Birmingham Business School. Rocio SánchezMangas is Associate Professor, Department of Economic Analysis, at Universidad Autónoma de Madrid. Olga Tregaskis is Professor of International Human Resource Management at Norwich Business School, University of East Anglia. Christian Lévesque is Professor at HEC Montréal. Anthony McDonnell is Senior Lecturer at the School of Management, University of South Australia. Javier Quintanilla is Professor of Managing People in Organizations at IESE Business School.

The project was supported by Canada's Social Sciences and Humanities Research Council (the SSHRC Major Collaborative Research Initiatives, Initiatives on the New Economy and International Opportunities Fund), the Fonds québécois de recherche sur la société et la culture (Équipes and Regroupements stratégiques), the Canada Research Chair on Globalization and Work, the Interuniversity Research Centre on Globalization and Work (CRIMT); Ireland's Labour Relations Commission, the Irish Research Council for the Humanities and Social Sciences, the University of Limerick Research Office; Spain's Ministries of Science and Innovation (ECO2009-10287) and Economy and Competitiveness (ECO201232854), the Directorate-General for Scientific Investigation of the Madrid region (Award 06/0009/2000), the BBVA Foundation (Ref. 216/06), the Autonomous University of Madrid/Banco Santander (Ref: CEAL-AL/2011-28), IESE Business School; the United Kingdom's Economic and Social Research Council (Awards RES-000-23-0305 and RES-062-23-2080); and the European Commission's International Research Staff Exchange Scheme (FP7 IRSES-GA-2008-230854 - INTREPID). The international survey data set is available from the Economic and Social Data Service (http://www.esds.ac.uk), deposit Ref: SN 7057, Surveying Employment Practices of Multinationals in Comparative Context. For information on the computer programs used to generate the results presented in the paper please contact the second author at Rocio.Sanchez@uam.es. Further details about the design, administration, and results of the surveys employed can be found in the article that introduces this special issue.
} 
$\mathrm{T}$ he human resource management (HRM) practices adopted by multinational companies (MNCs) have long attracted interest. Early ideas tended to assume a footloose group of firms unconstrained by local contexts and pursuing a global agenda of cost minimization (Fröbel et al. 1980). Research later established the continuing influence of the institutional contexts of MNCs' countries of origin and of the environments of the countries in which they operated (Ferner and Quintanilla 2002). More recent research has returned to the idea of global influences, arguing that a nationallevel framework gives insufficient attention to these forces and that firms may adopt common practices as they pursue what they perceive to be a global standard (Pudelko and Harzing 2007). Thus, our research pursues answers to two questions: (1) Do MNCs follow similar practices regardless of where they come from or are located, or are they more shaped by their origins and local contexts? (2) To the extent that practices are similar, is there any evidence of the adoption of global best standards? These questions are important for understanding the extent to which MNCs are globalized or embedded in national institutional systems. The answers have implications for how they manage themselves and how other actors engage with them.

Researchers have used three frameworks to attempt to understand the role of national and global institutional contexts in shaping the practices of firms: the neo-institutionalist analysis of regimes (Kostova 1999), the varieties of capitalism (VoC) literature (Hall and Soskice 2001), and the "system, societal and dominance" (SSD) approach (Smith and Meiksins 1995). Building on critiques of the first two, we develop the third. MNCs are heterogeneous, and they draw in complex ways on the "distinctive and variegated institutional configurations, including systems of employment relations, in which they are embedded" (Ferner and Quintanilla 2002: 249).

Previous survey research has set out to test the SSD model. Societal effects, that is, those arising from differences between individual countries, are the easiest to capture. We add to existing studies here with our analysis of detailed representative data on 1,100 MNC subsidiaries in four countries: Canada, Ireland, Spain, and the United Kingdom. Our distinctive contribution is to conceptually and empirically tease apart system and dominance effects; doing so is difficult because they both manifest as similarity in organizational practices, but our data are the richest to date to permit the necessary teasing out of complex influences. System effects reflect the characteristics of capitalism as a system and become visible at the firm level through the widespread adoption of common practices or standards; dominance effects arise from the leading role of dominant economies and the diffusion of practices originated in them. Clearly observed similarities could be due to either. It is therefore necessary to interrogate data through a series of related questions: Can we identify distinct practices of firms from dominant economies? If these practices are widespread, we can conclude that dominance effects exist. If there are also other patterns of commonality 
reflecting some global $\mathrm{HR}$ model, these strengthen arguments for system effects. Of our subsidiaries, 420 were owned by U.S. firms; we use differences between these dominant-economy firms and other firms to assess dominance effects. To assess system effects we look simultaneously for the widespread commonality in practices across host context and between U.S.owned and non-U.S. owned subsidiaries that are not explained by dominance effects.

\section{Frameworks of Analysis}

The influential, indeed hegemonic, neo-institutionalist approach (Ferner et al. 2012: 164) identifies the institutional profile of countries and measures the distance between countries (Kostova et al. 2008). It assumes the extent of transfer of practices by MNCs will be greater the shorter the institutional distance. It has particular strengths, notably in disaggregating the idea of transfer: a practice may formally operate in an MNC's subsidiary but only at the level of lip service. The limitation of this approach is that it gives little attention to global forces that may overwhelm national differences. Research in Eastern Europe, for example, has analyzed MNC subsidiaries in formerly communist countries that had been institutionally very different from leading global economies. This institutional distance did not necessarily retard the adoption of global standards; subsidiaries have at times gone out of their way to overtake their Western counterparts (Meardi and Tóth 2006). Björkman et al. (2007), studying subsidiaries in the United States, Finland, and Russia, similarly argue that those in the last country, though institutionally distant from MNCs' head offices, need "modern" practices more than those in the other countries as they try to catch up with the demands of a market economy. Institutional distance may be only one among a number of influences on practice.

The varieties of capitalism approach began from the now-familiar contrast between liberal market economies (LMEs) and coordinated market economies (CMEs). LMEs, with the United States as the exemplar, are driven by free market principles and neoliberal policies. In CMEs, notably Germany, social and political institutions, including labor market actors such as unions, shape economic activity. Firms from the first will tend to use employment systems based on individual incentives, while those from the latter will aim to build longer term commitment (Hall and Soskice 2001). MNCs from the relevant countries will then be expected to transfer such practices internationally within the constraints of having to operate in a host country of a different kind.

Such ideas have stimulated empirical research (Farndale et al. 2008; Pudelko and Harzing 2008). But these studies have some well-established limitations. From within the VoC approach, Hancké et al. (2007) list several: a tendency to focus on the national system, thus treating firms as the creatures of the systems in which they are based and giving insufficient 
attention to choice and variation; the treatment of types of economy as fixed and coherent things, rather than as complex historical products containing a blend of elements with contrasting features; and the downplaying of forces at the global level. This recognition of multiple lines of causality begins to acknowledge critiques from outside the tradition. Whitley (1999) identified six kinds of national business systems as opposed to only two, while Amable (2003), starting from a large set of empirical indicators, generated five groups. Thelen (2004) demonstrates the complex dynamics of skills systems in four countries and the drawbacks of reducing these to fixed types. Crouch (2005), building on his own extensive research on the evolution of national employment systems (Crouch 1993) as well as integrating work of this kind, argues that any national system reflects a continual "recombination" of elements drawn eclectically from many sources and not necessarily representing any simple model.

Although these post- or non-VoC theories underpin our own starting point, they generally focus on the level of national economies and variations between them. The SSD approach complements this idea with the reminder that varieties of capitalism are still indeed capitalism (Smith and Meiksins 1995; Sklair 2001). It thus identifies system effects at the level of capitalism as a whole; these include the need for accumulation and common forces arising from such things as technological innovation. The examples of Eastern Europe and Russia given above are illustrations of how system effects can propel hitherto backward economies toward the lead in the pursuit of global best practices. Dominance effects arise when a national system appears to have developed leading practices that are adopted elsewhere (Mayrhofer and Brewster 2005); familiar examples are the adoption of U.S. organizational structures in Europe (Djelic 1998) and the subsequent popularity of Japanese lean production techniques (Elger and Smith 2005). Societal effects are outcomes of nationally specific traditions. The neoinstitutionalist and VoC approaches tend to focus on this level, for example, differences between national contexts and their resultant effects on the ease of transfer of practices. In addition to identifying these effects, $\mathrm{SSD}$ also stresses the interaction of its three elements and historical contingency.

Some readings of SSD take it as identifying forces whose effects can be measured against each other. Are societal effects in some sense stronger than dominance effects (e.g., Lane 1997)? The authors of the approach reject this interpretation, stressing instead that the three influences interrelate and intersect in complex ways (Smith 2008: 41). Consider for example the "dominant" practice of lean production. Research has repeatedly shown that its adoption has varied among countries and that the nature of a lean regime has been subtly altered in practice (Kochan et al. 1997). There is room to mediate between an approach that reduces SSD to concrete measures and one that insists on historical contingency at the level of the individual firm. We develop hypotheses relating to each of the three dimensions 
of system, dominance, and society. We also measure contingency effects at the level of the firm.

Perhaps the greatest challenge to SSD is the separation of system and dominance effects. If we observe a common set of U.S.-style practices, is this because other countries have followed a dominant model from the United States or because of some systemwide logic? Existing research reflects this challenge. One study speaks of standardization toward global best practices, which it measures by the extent to which subsidiaries of non-U.S. firms adopt U.S. practices rather than following those of their home or host country (Pudelko and Harzing 2007, 2008). System and dominance effects are thus identified but not distinguished in terms of discrete effects.

Parry et al. (2008) analyzed North American MNCs in various countries of operation. They identified a set of U.S. HR practices and found that these were generally more common in LMEs than in CMEs. This is consistent with dominance effects, as well as with theories of institutional distance. As for societal effects, Farndale et al. (2008) found that MNC subsidiaries in CMEs had less leeway in their choice of HR arrangements than did those in LMEs. This is consistent with societal effects (and also VoC) because CME institutions are expected to impose more decisive constraints on firms than are approaches that are more driven by markets. These authors, however, could not assess firms from other countries or offer any specific explanation for how the interplay between different effects takes place. Lawler et al. (2011) similarly found some evidence of the use of a set of HR practices by U.S. MNCs across countries, albeit with considerable variation among host countries; this is consistent with system and dominance effects and also with societal-level adaptation, though these authors do not spell out the relevant causal processes in detail.

Stressing local adaptation, Brewster et al. (2008: 334-35) "found no evidence of the dominance of a coherent HRM paradigm reflecting the global dissemination of 'best practices'.... [M] anagers seem to combine a range of practices molded by institutionally embedded opportunities and constraints operating at a range of levels." On their first point, however, they also show that, in a given country, domestic and foreign-owned MNCs have similar HRM practices, which might suggest that, as MNCs, they are stronger bearers of global effects than are domestic firms; furthermore the authors do not say what a "coherent HRM paradigm" comprises, so that it is not clear against what standard of global practices MNCs are being judged. Their second point is consistent with a contingency account, though they do not specifically disentangle system, dominance, and societal effects.

These previous studies have found it hard to distinguish among system, societal, and dominance effects. Some of them analyze only North American firms while others study MNCs as a group as compared to non-MNCs. Such data make it impossible to test for dominance effects by comparing MNCs from dominant economies with others. System effects are also hard to unravel because it is not clear whether commonalities reflect country-oforigin or wider systemic influences. Our data are better suited to addressing 
such issues because they embrace U.S.- and non-U.S. firms; permit comparison within a representative set of MNCs; offer measurement of HRM practices against a defined standard; and allow for the competing forces of SSD to be examined and, in particular, for system effects to be deduced from patterns in the data that do not fit dominance or societal effects.

\section{Operationalizing SSD}

As we have noted, societal effects are the simplest to measure. The most basic expectations are that differences in the use of HRM practices exist between countries and that they remain when other influences are controlled for. For VoC, these differences are patterned. Hall and Gingerich (2009) develop a scale of degree of coordination where the United States scores 0.00 and Germany scores 0.95 . Of our four countries, Spain has an index of 0.57 , compared to Canada's 0.13, and 0.07 for the United Kingdom and 0.29 for Ireland. Indeed, on the OECD's Employment Protection Index for 2008, Spain scores higher than other CMEs, with a score of 3.11 against Germany's 2.63 (OECD 2008). Canada, at 1.02, is close to the United States, the country with the weakest protection, which has an index of 0.85 . The United Kingdom and Ireland score 1.09 and 1.39, respectively. VoC thus expects Spain to be distinct from the other three countries. When we identify sets of HRM practices, firms from LMEs are expected to use individualized employment practices such as contingent pay. Employment protection legislation affects nonmanagerial employees more than managers, and VoC accounts would thus expect Spain to be most distinctive in relation to nonmanagerial employees.

We prefer a less deterministic reading and do not propose specific societal effects, but consider instead how they might work in light of the results as a whole. If we consider Spain and the United Kingdom, the two countries furthest apart on the Hall-Gingerich scale, there is in fact more openness in Spain to ideas from outside than might be expected; some scholars even argue that Spain may be the more open. The United Kingdom, though having relatively weak labor laws, also has a strongly established institutional tradition. Some scholars see the United Kingdom as uniquely trapped in a "low skills equilibrium" from which firms find it hard to escape (see Keep et al. 2006). The implication is that innovative ideas might be hard to implement in a context such as the United Kingdom. Spain, by contrast, has lacked such a tradition in terms of management practices. As Ferner et al. (2001: 124) note, "the Spanish management model is more open than the British"; it has experienced a "confluence of styles and practices...transmitted to an important extent through the operations of MNCs." Bayo-Moriones and Galdon-Sanchez (2010) similarly characterize Spain as malleable but regulated. Therefore, one might expect any innovation in Spain to be associated with practices affecting managers, while those for nonmanagerial employees may be more constrained by legal requirements. 
As for system and dominance effects, we use three ways to disentangle them. First, we identify what a global HRM paradigm comprises and then test for its presence. This has not been done explicitly to date. If its adoption is widely diffused, we can conclude that system effects may be present. We test further to see whether some expected dominance or societal effects do not in fact exist. This would leave system effects as the remaining possible cause of observed patterns. We would, of course, need further evidence of relevant mechanisms to sustain this account.

Second, we can follow those who see U.S. practices as having a renewed global dominance. This dominance reflects the weakening of alternative models, such as the Japanese or the German, and the rise of the strongly U.S.-influenced model of financialized capitalism (Fligstein 2001; Dore 2008) and the global position of the "Washington consensus" (Stiglitz 2002). If specifically U.S. practices are common, dominance effects may exist.

Third, we ask where the practices are found. One reading of dominance effects, consistent with neo-institutionalism, is that these will spread from leading countries to those countries closest to them. A VoC explanation would be that, if leading countries are LMEs, then similar practices will be most likely in other LMEs; however, if these patterns are not present then arguments for system effects are strengthened.

Specifically, system effects are indicated by the widespread adoption of a set of global HRM practices. If, moreover, adoption is common across different parts of the work force, this idea is strengthened. They are to a degree inferred from the gaps and anomalies in other explanations. We therefore discuss them last in the empirical analysis. If common patterns persist when we take account of dominance and societal effects and other contingencies, the idea of system effects remains a plausible one. Finally, if we find that HRM practices diffuse in ways not consistent with other explanations, system effects may be present. Thus Spain is institutionally different from our other countries and has historically also been the most excluded from the global economic system. Neo-institutionalism and $\mathrm{VoC}$ would thus predict that Spain would be the least likely to deploy global practices. If this is not the case, system effects remain a plausible explanation.

Dominance effects are indicated, first, by the diffusion of practices associated with a dominant economy, which we take to be the United States. It is well established that U.S. MNCs use centralized approaches to HRM and also grant subsidiaries little autonomy (Almond et al. 2005). We would thus expect them to score high on those aspects of HRM practices related to the control of the performance of employees.

Some readings of dominance effects, consistent with neo-institutionalism, expect the effects to diffuse to countries similar to the United States. In this case, Canada is clearly the most similar institutionally to the United States of the countries in our study, given, for example, the Wagner Act-style of labor law it shares with the United States; geographical proximity may also be important. By the same logic, U.S.-style HRM practices would be expected to be least common in Spain. Our own reading of dominance effects, follow- 
ing Smith (2008), is that they should not be interpreted in such a onedimensional way: they interact with other measures. But we acknowledge and test the alternative reading.

To summarize, if societal effects are very strong we expect differences among our four countries of operation. If VoC or institutional distance factors are at work, we expect Spain to be different from the other three countries. If dominance effects are present, we expect evidence of U.S.-style practices across all four countries and especially in the three LMEs. System effects will be indicated by widespread take-up of a common set of practices that correspond to some idea of best practices and also by wide diffusion of these practices that cannot be explained by the other two sets of effects. We need to disaggregate HRM practices in two ways: in terms of different dimensions, to refine the test of U.S. dominance effects; and in relation to different groups of employees, to test whether societal constraints are strongest in relation to nonmanagerial employees, for whom employment protection laws are more salient than they are for managers.

\section{HRM Practices}

The debate on HRM practices has been extensive and contentious (Becker and Huselid 2006; Kaufman 2010). Much of the contention turns on their effects on employees. But we are interested here in the practices as dependent variables and thus this specific area of contention is less central. HRM practices are properties of firms, not national systems. It is therefore necessary to place "the firm at the centre of analysis" (Hancké et al. 2007: 5). The practices are not a random list. According to Wright and Boswell (2002: 253), there is an emerging consensus "around conceptual categories of employee skills, motivation and empowerment." As Boselie et al. (2005) show, the most popular way to capture this consensus is the Abilities, Motivation, and Opportunity (AMO) framework. We can take this framework as establishing a benchmark of best or leading practices and thus establish how far MNCs share a set of such practices. Abilities embraces the skills and competencies that workers possess. Motivation addresses the factors that give workers incentives to deploy their abilities. Opportunity covers means through which the resulting commitment can be put into practice.

There are some unresolved issues about which concrete practices to include under each heading. Some scholars place practices such as appraisal within Abilities (Boxall and Purcell 2003: 144). Yet appraisal is at least as much about systems of control as it is about abilities. The AMO framework indeed rather underplays the fact that HRM is not just about releasing workers' abilities and motivating them. Any HR system needs discipline and control, as generations of labor process scholars have pointed out (Edwards 1979): Managers need to regulate workers so that they work in ways consistent with organizational goals. The specific control elements of high-performance systems, such as the demands that they can put on workers, are also well established (Thompson and Harley 2007). 
We have relatively few measures that might be classified as Abilities and thus say little about this dimension. Therefore we will refer to the Motivation, Opportunities, and Control dimensions of HR practices. We follow the established practice in studies using the AMO framework of treating each dimension as independent, rather than aggregating them as a single measure.

\section{Data, Methods, and Measurement}

The key independent variables are the countries of operation and origin of the MNCs. The former are simply the four countries where the subsidiaries were located: Canada, Ireland, Spain, and the United Kingdom. As to the country of origin of the companies owning the subsidiaries under study, the United States has by far the greatest number, with the United Kingdom, France, Germany, Japan, and the Nordic countries also having significant representation. For some studies in this special issue, comparison between these individual countries-of-origin is important. We are interested here in the LME-CME contrast and also in any specifically U.S.-based dominance effects. The sample was therefore grouped by country of origin as follows: U.S.-owned MNCs (420 in number) were thus compared to MNCs from the three most heavily represented countries of origin generally considered to be liberal market economies, namely, the United Kingdom, Canada, and Ireland ( $n=223)$ and to the remaining 457 subsidiaries owned by multinationals from broadly CME economies. An alternative approach is to classify countries-of- origin on the Hall-Gingerich (2009) scale; similar results were obtained.

\section{Identification and Measurement of HRM Practices}

In addition to country of origin, we also need to control for other possible influences. Some studies look at a wide-ranging group of employment practices, including trends in numbers employed and use of nonstandard labor (Brewster et al. 2008; Parry et al. 2008). This lacks precision if the goal is to identify a specific global model of practices that are chosen by MNCs, as opposed to measuring all the dimensions on which they may differ from domestic firms. Lawler et al. (2011) use extensive sets of indicators in relation to four areas: training and development; staffing (for example, approaches to selection); compensation; and workplace empowerment. Björkman et al. (2007) use a similar list, though with the addition of communication. Pudelko and Harzing (2007) list seven areas, though two of these arguably do not measure HR practices specifically; the other five embrace recruitment, training, assessment, incentives, and communication. Walsworth and Verma (2007) have a similar list of high-performance practices. We cover compensation, empowerment, training and development, communication, and assessment.

Some studies ask respondents to consider pairs of opposing statements about the use of practices (Pudelko and Harzing 2007) or to report the 
Table 1. HRM Practices

\begin{tabular}{lcc}
\hline Practice & LOG & Managers \\
Motivation & & \\
Policy to pay > median pay in the country & - & $\mathrm{Y}$ \\
Use of share-ownership schemes & - & $\mathrm{Y}$ \\
Use of profit sharing & - & $\mathrm{Y}$ \\
Use of share options & $\mathrm{Y}$ & - \\
Communication: use of briefing groups & $\mathrm{Y}$ & - \\
Communication: 2-way & $\mathrm{Y}$ & - \\
Communication: newsletters, etc. & $\mathrm{Y}$ & - \\
Information provision: financial plans & $\mathrm{Y}$ & - \\
Information provision: staffing plans & - & \\
Information provision: investment plans & - & $\mathrm{Y}$ \\
Opportunity & - & $\mathrm{Y}$ \\
Use of short-term international assignments & - & $\mathrm{Y}$ \\
Use of long-term international assignments & $\mathrm{Y}$ & - \\
Use of global management training & $\mathrm{Y}$ & - \\
Use of team working & & \\
Use of problem-solving groups & $\mathrm{Y}$ & $\mathrm{Y}$ \\
Control & $\mathrm{Y}$ & $\mathrm{Y}$ \\
Use of performance appraisal & $\mathrm{Y}$ & $\mathrm{Y}$ \\
Use of variable pay & - & $\mathrm{Y}$ \\
\hline Use of forced distribution or ranking in appraisal & \\
Assessment against set of global competencies &
\end{tabular}

extent to which a practice is used (Lawler et al. 2011). The difficulty here is that perceptions are necessarily involved. We would want respondents to use other MNCs as their benchmark, but they might well not know about other firms or use some other benchmark, such as firms in general. We preferred to ask about the presence of concrete practices. Respondents were also not asked to estimate the proportion of employees covered by certain practices. We had one set of perceptual questions, but these related to the company itself and not to implicit comparator companies.

Ferner and Almond (2013) draw directly on dominance theories to identify a characteristically U.S. "pay and performance management system" that embraces appraisal systems, contingent pay, and share ownership and profit-related pay (see Jacoby 1997). We draw on these ideas in particular as we look at dominance effects: U.S. firms are most likely to deploy practices falling within the control dimension of practices.

We asked separately about two groups of employees: managers and the largest occupational group (LOG). Managers were defined as those in managerial positions above the level of first-line supervision and the LOG as a specifically nonmanagerial group; and we offered illustrations if necessary. Our strategy here is to ground practices in relation to concrete, named groups and also to reflect the fact that different groups of employees may be managed differently.

Though we do not follow a strictly high-performance model, we are interested in practices that reflect some kind of best practices model and that specifically illustrate the motivation, opportunity, and control aspects of an HRM system. Table 1 shows the full list in relation to managers and the 
LOG. Some of the relevant concepts are best measured at the level of the individual workplace, for example the extent and nature of training (Jones et al. 2010). We thus had few measures of abilities.

We coded all variables as dummy variables, with 1 indicating the presence of the practice. In many cases, the underlying concept, for example, whether or not share-owning schemes were in place, is binary. In relation to the four questions about global assignments, training, and competencies, however, the survey question asked about the extent of use on a five-point scale. For consistency with the other measures, we reduced these indicators to binary measures taking the two categories of greatest use to indicate clear presence of a practice. We had a total of 22 practices or 19 if we count those in common across the two groups only once. Some of these are summaries of even more detailed indicators. For example, in relation to communication with the LOG we asked about 8 forms, plus "other"; the three listed combine the key ones.

The number of practices adopted in this analysis compares well with other studies, for example Pudelko and Harzing's 20 (2007, 2008) and Brewster et al.'s 15 (2008). As to those selected, we are perhaps lightest on training and development. Despite these limitations, we have a range of practices indexing relevant concepts.

\section{The Strategic Context of the MNC}

Because HRM practices are properties of firms, we need to take account of firms' organizational structures. For our purposes, these factors are mainly control variables: Do SSD effects remain even after we have controlled for the structure of the firm? But the SSD framework also stresses the choices made by firms, and we consider whether indicators of choice affect the takeup of practices. We address the integration of the MNC and its HR structures.

There is a clear line of theory saying that HRM practices will be most developed in integrated firms, because such practices promote the sharing of resources across subsidiaries. Less integrated firms benefit less from the use of these practices. An alternative view would say that the use of practices is driven by broader competitive or isomorphic pressures and that the structure of firms will have little effect. We are agnostic as between these two positions. We measured the relevant variables as follows:

Interdependencies were measured by two dummy variables. One indicated whether the national subsidiary supplied to other parts of the worldwide company or not. The second identified whether the national subsidiary was supplied by other parts of the worldwide operations. These were combined into one measure with four categories: supplying to and from; supplying only to; supplied only by; and neither.

Standardization indicates whether the firm's product or service was adapted to local markets or standardized at a regional or global level.

Organization structure was measured by three binary variables indicating whether the firm used product divisions, whether it had regional divisions, and whether it had both of these structures. 
The size of the company was measured in terms of the size of the worldwide company and of the subsidiary, each assessed in terms of numbers of employees and categorized to reflect the fact that several respondents could estimate size only in ranges.

A firm's HR system is important in its use of practices such as organizational learning (McDonnell et al. 2010; Tregaskis et al. 2010). We include two indicators of the extent of global HR structures and policies. We expect positive effects on the use of HRM practices if choice is important.

\begin{abstract}
International HR committee measured whether the MNC had a formal committee of senior managers responsible for developing HR policies across countries. This was dummy coded with 1 indicating presence of such a committee. We also had other measures such as whether the worldwide company used a human resource information system. We examined these, but their results were similar to those for the most straightforward measure of the presence of a committee.
\end{abstract}

HR philosophy measured whether the MNC had a worldwide philosophy on the management of its workforce that governed all global operations. This was measured on a 5-point scale of agreement as to how far a philosophy existed.

Finally, we included three other control variables. The sector of operation of a firm was dichotomized as production and service firms. In so far as practices such as teamwork and associated ideas such as lean production were strongly associated with manufacturing, we would expect take-up to be greater in the production sector. Trade union recognition measured whether the subsidiary recognized trade unions. There has been considerable debate on whether unions promote or retard use of HRM practices. It may also be that the effects are greater in relation to the LOG than to managers.

Workforce skill level measured whether the largest occupations group of the subsidiary was one of technical/professional, sales staff, clerical/administrative staff, or manual operatives.

\title{
Mode of Analysis and Data Description
}

We analyzed the data in two ways. First, we classified each of the individual measures listed in Table 1 in terms of country of operation and the contrast by country of origin between U.S.-owned firms, firms from other LMEs, and all other (CME) firms. The results from this descriptive analysis (available on request) suggested some patterns that were interrogated further. All the descriptive statistics are based on weighted data for each country.

Second, we aggregated the measures under each of the concepts of motivation, opportunity, and control to create six summary indices (that is, three for managers and three for the LOG). These indices count the number of practices under each heading. The results were consistent with the examination of the individual measures. How did we account for missing data? One strategy is to count any affirmation that a practice exists as a yes, treating all no and don't know replies as the default category. This may, however, force undue clarity on respondents. We preferred the more conservative approach of treating don't know replies as missing, and eliminating cases 
Table 2. Dependent Variables: Mean Values by Country of Origin and Country of Operations

\begin{tabular}{|c|c|c|c|c|c|c|}
\hline \multirow[b]{2}{*}{ Variable } & \multicolumn{3}{|c|}{$L O G$} & \multicolumn{3}{|c|}{ MANAGERS } \\
\hline & LMOTIV & $L O P P$ & LCONTROL & MMOTIV & MOPP & MCONTROL \\
\hline Overall mean & 4.8 & 1.4 & 2.0 & 1.6 & 2.1 & 3.0 \\
\hline Range & $0-6$ & $0-2$ & $0-3$ & $0-4$ & $0-3$ & $0-4$ \\
\hline$n$ & 1,057 & 1,084 & 820 & 839 & 807 & 743 \\
\hline \multicolumn{7}{|l|}{ Country of origin } \\
\hline United States & 4.9 & 1.4 & 2.0 & 1.9 & 2.1 & 3.2 \\
\hline LME (others) & 4.7 & 1.3 & 1.8 & 1.9 & 1.9 & 2.8 \\
\hline CME & 4.7 & 1.4 & 1.9 & 1.3 & 2.2 & 3.0 \\
\hline Significant differences between & No & No & Yes & Yes & Yes & Yes \\
\hline groups at $5 \%$ level ( $p$ value) & $(0.182)$ & $(0.173)$ & $(0.002)$ & $(0.000)$ & $(0.021)$ & $(0.000)$ \\
\hline Effect size $\left(\eta^{2}\right)$ & 0.003 & 0.003 & 0.015 & 0.057 & 0.009 & 0.046 \\
\hline \multicolumn{7}{|l|}{ Country of operations } \\
\hline United Kingdom & 4.7 & 1.5 & 1.9 & 1.6 & 2.3 & 2.9 \\
\hline Canada & 5.1 & 1.2 & 1.7 & (a) & 1.5 & 2.8 \\
\hline Ireland & 4.7 & 1.3 & 2.0 & 1.6 & 2.1 & 3.1 \\
\hline Spain & 4.7 & 1.4 & 2.1 & 1.7 & 2.4 & 3.3 \\
\hline Significant. differences between & Yes & Yes & Yes & No & Yes & Yes \\
\hline groups at $5 \%$ level ( $p$-value) & $(0.000)$ & $(0.000)$ & $(0.000)$ & $(0.510)$ & $(0.000)$ & $(0.000)$ \\
\hline Effect size $\left(\eta^{2}\right)$ & 0.018 & 0.029 & 0.036 & 0.002 & 0.111 & 0.064 \\
\hline
\end{tabular}

Notes: $\eta^{2}$ is the eta-squared statistic derived from ANOVA, analogous to $\mathrm{R}^{2}$ in regression equations.

Definitions:

LMOTIV: 3 items of information provision plus 3 items of communication

LOPP: Use of teamwork and/or problem-solving groups

LCONTROL: Use of performance appraisal, forced distribution in appraisal, use of variable pay MMOTIV: Use of pay > median, use of profit share, share options, share ownership

MOPP: Use of short- or long-term international assignments, use of global management training MCONTROL: Use of performance appraisal, forced distribution in appraisal, use of variable pay, assessment against global competencies.

Not available for Canada.

with any such replies from the indices. The result is that we have variable sample sizes across the six indicators. We deployed bivariate analyses and multivariate modeling to the indices. For the latter, we also tested our models on a consistent set of observations $(n=640)$ across all six indices; the results were consistent with the wider data set on which we report. We prefer this data set because it uses the maximum information from the sample as well as having larger numbers and thus more accurate estimates of confidence intervals.

The first panel of Table 2 reports the mean of each measure, the observed range, and the number of observations. The second panel shows a breakdown against the MNC's country of origin and the results of significance testing for differences across the three categories and the effect sizes. For example, on the measure of motivation for the LOG there was no difference between U.S.-owned subsidiaries, those from other LMEs, or those from CMEs. The third panel does the same across the four countries of operation.

One preliminary result concerns the relationships among the aspects of motivation, opportunity, and control. The indices were positively but not 
strongly related to each other, and this suggests that they indeed capture different dimensions. This positive association does not support the view that one form of HRM is a substitute for another but rather is consistent with arguments that HRM systems tend to comprise complementary elements and that firms do not, for example, rely on motivation as an alternative to control (Ferner 2000).

Examination of the distribution of the measures (not shown) revealed a spread across the range rather than concentration at the potentially highperformance end of the range. This is consistent with Brewster et al.'s argument(2008) that there is no coherent HRM paradigm among MNCs in the sense of a complete package that is widely adopted, as well as with nationallevel studies showing a bell-shaped distribution of HRM practices (Bryson et al. 2007; Kaufman 2010). Yet to expect such a package would be to impose a very strong test. We show that there was evidence of adoption of the HRM paradigm, albeit in less than complete ways.

Multivariate modeling used the six measures from Table 2 as the dependent variables; that is, we count the number of practices under each measure. Because of the count nature of these variables, we used Poisson models to overcome the limitations of linear modeling. ${ }^{1}$ Since the Poisson model is nonlinear, the estimated average partial effects of the explanatory variables are not directly given by the estimated coefficients. They are instead a nonlinear function of these coefficients and the explanatory variables. The Poisson estimates and estimated partial effects are presented in Table $3 .{ }^{2}$

The results in Table 3 show, first, that there is a binary variable for whether or not the subsidiary is owned by an MNC based in the relevant country or by a foreign MNC. We treat this largely as an additional control variable. Second comes the country of operation. Third, we distinguish further by identifying those firms that are, for example, owned and based in the United Kingdom as compared to those owned and based in one of the other three countries. The purpose of this is to assess whether such locally oriented subsidiaries are in some way different from more globally influenced ones. Fourth, we have the country of origin of the MNC (United States, other $\mathrm{LME}$, and $\mathrm{CME}$ ). Then come controls for the structure of the firm and its size. The two measures reflecting HR choice (an international HR committee and the presence of a philosophy) come next. Finally, there are controls for the sector of operation, union recognition, and measures of the skill structure of the work force. The Appendix gives the correlation matrix for all these variables; the low levels of correlation among them suggest that multicollinearity was not a problem.

\footnotetext{
'The Poisson model imposes some restrictions, mainly that the conditional mean and conditional variance coincide. In many applications this assumption is very restrictive, since it is quite common to find evidence of overdispersion (conditional variance higher than that under the Poisson assumption). However, we have not found evidence of this problem in our data, i.e., the Poisson assumptions were not unduly restrictive. Further, to control for potential misspecifications in the variance, we have performed the estimation with robust standard errors.

${ }^{2}$ The Poisson estimated coefficients are available from the authors upon request.
} 
Table 3. Estimated Average Partial Effects from Poisson Estimates

\begin{tabular}{|c|c|c|c|c|c|c|}
\hline \multirow[b]{2}{*}{ Variable } & \multicolumn{3}{|c|}{$L O G$} & \multicolumn{3}{|c|}{ MANAGERS } \\
\hline & LMOTIV & $L O P P$ & LCONTROL & ММОтTИ & $M O P P$ & MCONTROI \\
\hline \multicolumn{7}{|l|}{ Ownership Reference: Foreign } \\
\hline Domestic & $\begin{array}{c}0.209 \\
(0.258)\end{array}$ & $\begin{array}{c}0.386^{* * * *} \\
(0.134)\end{array}$ & $\begin{array}{c}0.079 \\
(0.152)\end{array}$ & $\begin{array}{c}0.386^{*} \\
(0.223)\end{array}$ & $\begin{array}{c}0.667 * * \\
(0.277)\end{array}$ & $\begin{array}{c}-0.271^{*} \\
(0.163)\end{array}$ \\
\hline \multicolumn{7}{|l|}{ Reference: Uniled Kingdom } \\
\hline Canada & $\begin{array}{c}0.170 \\
(0.136)\end{array}$ & $\begin{array}{c}-0.256^{* * * *} \\
(0.075)\end{array}$ & $\begin{array}{c}-0.239 * * \\
(0.102)\end{array}$ & - & $\begin{array}{c}-0.718^{* * *} \\
(0.126)\end{array}$ & $\begin{array}{c}-0.027 \\
(0.098)\end{array}$ \\
\hline Ireland & $\begin{array}{c}0.035 \\
(0.119)\end{array}$ & $\begin{array}{c}-0.123^{*} \\
(0.070)\end{array}$ & $\begin{array}{c}0.021 \\
(0.077)\end{array}$ & $\begin{array}{c}0.090 \\
(0.125)\end{array}$ & $\begin{array}{l}-0.098 \\
(0.105)\end{array}$ & $\begin{array}{c}0.115 \\
(0.090)\end{array}$ \\
\hline Spain & $\begin{array}{c}-0.092 \\
(0.117)\end{array}$ & $\begin{array}{c}0.034 \\
(0.071)\end{array}$ & $\begin{array}{c}0.163^{*} * \\
(0.079)\end{array}$ & $\begin{array}{c}0.284 * * \\
(0.126)\end{array}$ & $\begin{array}{c}-0.096 \\
(0.107)\end{array}$ & $\begin{array}{c}0.283^{* * *} \\
(0.084)\end{array}$ \\
\hline $\begin{array}{l}\text { Domestic MNC by country } \\
\text { Reference: Domestic in United } \\
\text { Kingdom }\end{array}$ & & & & & & \\
\hline Domestic in Canada & $\begin{array}{c}0.140 \\
(0.288)\end{array}$ & $\begin{array}{c}-0.353^{* *} \\
(0.162)\end{array}$ & $\begin{array}{c}0.106 \\
(0.294)\end{array}$ & 一 & $\begin{array}{c}0.056 \\
(0.343)\end{array}$ & $\begin{array}{c}0.123 \\
(0.227)\end{array}$ \\
\hline Domestic in Ireland & $\begin{array}{c}-0.676^{* *} \\
(0.302)\end{array}$ & $\begin{array}{c}-0.408^{* * *} \\
(0.135)\end{array}$ & $\begin{array}{c}-0.153 \\
(0.190)\end{array}$ & $\begin{array}{l}-0.338 \\
(0.229)\end{array}$ & $\begin{array}{l}-0.040 \\
(0.258)\end{array}$ & $\begin{array}{c}0.237 \\
(0.203)\end{array}$ \\
\hline Domestic in Spain & $\begin{array}{c}-0.302 \\
(0.292)\end{array}$ & $\begin{array}{c}-0.396^{* * *} \\
(0.117)\end{array}$ & $\begin{array}{l}-0.090 \\
(0.182)\end{array}$ & $\begin{array}{c}-0.393^{*} \\
(0.213)\end{array}$ & $\begin{array}{l}-0.282 \\
(0.241)\end{array}$ & $\begin{array}{l}0.477^{* *} \\
(0.225)\end{array}$ \\
\hline \multicolumn{7}{|l|}{$\begin{array}{l}\text { Country of origin Reference: } \\
L M E \text { (others) }\end{array}$} \\
\hline United States & $\begin{array}{c}0.146 \\
(0.156)\end{array}$ & $\begin{array}{c}0.076 \\
(0.093)\end{array}$ & $\begin{array}{c}0.115 \\
(0.105)\end{array}$ & $\begin{array}{l}-0.029 \\
(0.118)\end{array}$ & $\begin{array}{c}0.551^{* * * *} \\
(0.179)\end{array}$ & $\begin{array}{c}0.138 \\
(0.106)\end{array}$ \\
\hline CME & $\begin{array}{c}0.092 \\
(0.159)\end{array}$ & $\begin{array}{c}0.040 \\
(0.092)\end{array}$ & $\begin{array}{c}0.042 \\
(0.106)\end{array}$ & $\begin{array}{l}-0.511 * * * \\
(0.127)\end{array}$ & $\begin{array}{c}0.571^{* * * *} \\
(0.186)\end{array}$ & $\begin{array}{l}-0.050 \\
(0.108)\end{array}$ \\
\hline \multicolumn{7}{|l|}{ Inter-dependencies } \\
\hline $\begin{array}{l}\text { Subsidiary supplies other } \\
\text { parts of the MNC } \\
\text { Survey country operations } \\
\text { supplied by other parts }\end{array}$ & $\begin{array}{c}0.095 \\
(0.084) \\
0.030 \\
(0.089)\end{array}$ & $\begin{array}{c}0.212^{* * *} \\
(0.056) \\
0.015 \\
(0.059)\end{array}$ & $\begin{array}{c}0.102 * \\
(0.059) \\
0.054 \\
(0.061)\end{array}$ & $\begin{array}{c}0.199 * * \\
(0.092) \\
0.005 \\
(0.100)\end{array}$ & $\begin{array}{c}0.045 \\
(0.085) \\
0.016 \\
(0.094)\end{array}$ & $\begin{array}{c}0.169 * * * \\
(0.061) \\
0.047 \\
(0.061)\end{array}$ \\
\hline \multicolumn{7}{|l|}{$\begin{array}{l}\text { Standardization Reference: } \\
\text { Globally standardized products }\end{array}$} \\
\hline Products adapted locally & $\begin{array}{c}0.038 \\
(0.086)\end{array}$ & $\begin{array}{l}-0.013 \\
(0.054)\end{array}$ & $\begin{array}{l}-0.113^{*} \\
(0.060)\end{array}$ & $\begin{array}{c}0.061 \\
(0.093)\end{array}$ & $\begin{array}{l}-0.109 \\
(0.086)\end{array}$ & $\begin{array}{l}-0.059 \\
(0.060)\end{array}$ \\
\hline \multicolumn{7}{|l|}{ Organization structure } \\
\hline Product divisions & $\begin{array}{l}-0.151 \\
(0.152)\end{array}$ & $\begin{array}{c}0.279 * * * \\
(0.117)\end{array}$ & $\begin{array}{c}0.020 \\
(0.117)\end{array}$ & $\begin{array}{c}0.149 \\
(0.204)\end{array}$ & $\begin{array}{c}0.967 * * * \\
(0.254)\end{array}$ & $\begin{array}{l}0.255^{* *} \\
(0.116)\end{array}$ \\
\hline Regions & $\begin{array}{l}-0.096 \\
(0.130)\end{array}$ & $\begin{array}{l}0.169 * \\
(0.099)\end{array}$ & $\begin{array}{c}0.114 \\
(0.102)\end{array}$ & $\begin{array}{c}0.176 \\
(0.172)\end{array}$ & $\begin{array}{c}0.708 * * * \\
(0.205)\end{array}$ & $\begin{array}{c}0.057 \\
(0.098)\end{array}$ \\
\hline Both & $\begin{array}{l}-0.154 \\
(0.121)\end{array}$ & $\begin{array}{l}0.173^{* *} \\
(0.085)\end{array}$ & $\begin{array}{c}0.065 \\
(0.095)\end{array}$ & $\begin{array}{l}0.287^{*} \\
(0.157)\end{array}$ & $\begin{array}{c}0.702^{* * *} \\
(0.167)\end{array}$ & $\begin{array}{l}-0.001 \\
(0.092)\end{array}$ \\
\hline \multicolumn{7}{|l|}{$\begin{array}{l}\text { Subsidiary size Reference: } \\
<500 \text { employees }\end{array}$} \\
\hline 500-999 employees & $\begin{array}{l}-0.086 \\
(0.108)\end{array}$ & $\begin{array}{l}-0.096 \\
(0.066)\end{array}$ & $\begin{array}{l}-0.029 \\
(0.068)\end{array}$ & $\begin{array}{c}0.246^{* *} \\
(0.124)\end{array}$ & $\begin{array}{c}0.103 \\
(0.118)\end{array}$ & $\begin{array}{r}-0.070 \\
(0.076)\end{array}$ \\
\hline 1,000 or more employees & $\begin{array}{c}-0.095 \\
(0.096)\end{array}$ & $\begin{array}{l}-0.029 \\
(0.059)\end{array}$ & $\begin{array}{c}-0.181^{* * *} \\
(0.065)\end{array}$ & $\begin{array}{c}0.269 * * \\
(0.108)\end{array}$ & $\begin{array}{c}0.235^{* *} \\
(0.092)\end{array}$ & $\begin{array}{r}-0.085 \\
(0.059)\end{array}$ \\
\hline \multicolumn{7}{|l|}{$\begin{array}{l}\text { Worldwide size Reference: } \\
<1,000 \text { employees }\end{array}$} \\
\hline $1,000-4,999$ employees & $\begin{array}{l}0.405^{*} \\
(0.215)\end{array}$ & $\begin{array}{l}-0.005 \\
(0.113)\end{array}$ & $\begin{array}{c}0.013 \\
(0.134)\end{array}$ & $\begin{array}{l}-0.139 \\
(0.215)\end{array}$ & $\begin{array}{l}-0.237 \\
(0.218)\end{array}$ & $\begin{array}{l}-0.002 \\
(0.164)\end{array}$ \\
\hline
\end{tabular}


Table 3. Continued

\begin{tabular}{|c|c|c|c|c|c|c|}
\hline \multirow[b]{2}{*}{ Variable } & \multicolumn{3}{|c|}{$L O G$} & \multicolumn{3}{|c|}{ MANAGERS } \\
\hline & LMOTIV & $L O P P$ & LCONTROL & MMOTIV & MOPP & MCONTROL \\
\hline $5,000-29,999$ employees & $\begin{array}{l}0.430^{* *} \\
(0.216)\end{array}$ & $\begin{array}{l}-0.041 \\
(0.111)\end{array}$ & $\begin{array}{c}0.052 \\
(0.135)\end{array}$ & $\begin{array}{c}0.022 \\
(0.228)\end{array}$ & $\begin{array}{l}-0.256 \\
(0.224)\end{array}$ & $\begin{array}{c}0.106 \\
(0.164)\end{array}$ \\
\hline $30,000-59,999$ employees & $\begin{array}{c}0.544 * * \\
(0.247)\end{array}$ & $\begin{array}{l}-0.042 \\
(0.126)\end{array}$ & $\begin{array}{c}0.154 \\
(0.158)\end{array}$ & $\begin{array}{c}0.363 \\
(0.288)\end{array}$ & $\begin{array}{c}0.122 \\
(0.252)\end{array}$ & $\begin{array}{c}0.286 \\
(0.183)\end{array}$ \\
\hline 60,000 or more employees & $\begin{array}{c}0.693^{* * *} \\
(0.243)\end{array}$ & $\begin{array}{c}0.102 \\
(0.131)\end{array}$ & $\begin{array}{c}0.218 \\
(0.154)\end{array}$ & $\begin{array}{c}0.128 \\
(0.260)\end{array}$ & $\begin{array}{c}0.175 \\
(0.251)\end{array}$ & $\begin{array}{c}0.289 \\
(0.179)\end{array}$ \\
\hline International $\mathrm{HR}$ committee & $\begin{array}{c}0.397 * * * \\
(0.085)\end{array}$ & $\begin{array}{l}0.126 * * \\
(0.052)\end{array}$ & $\begin{array}{c}0.040 \\
(0.055)\end{array}$ & $\begin{array}{l}0.197^{* *} \\
(0.088)\end{array}$ & $\begin{array}{c}0.295^{* * *} \\
(0.085)\end{array}$ & $\begin{array}{l}0.151^{*} \\
(0.058)\end{array}$ \\
\hline $\begin{array}{l}\text { Existence of a global } \\
\text { philosophy? Reference: } \\
\text { disagree strongly }\end{array}$ & & & & & & \\
\hline Disagree & $\begin{array}{l}-0.069 \\
(0.177)\end{array}$ & $\begin{array}{l}-0.062 \\
(0.109)\end{array}$ & $\begin{array}{c}0.126 \\
(0.131)\end{array}$ & $\begin{array}{l}-0.065 \\
(0.173)\end{array}$ & $\begin{array}{l}-0.132 \\
(0.187)\end{array}$ & $\begin{array}{c}0.098 \\
(0.138)\end{array}$ \\
\hline Neither & $\begin{array}{l}-0.014 \\
(0.173)\end{array}$ & $\begin{array}{c}0.085 \\
(0.111)\end{array}$ & $\begin{array}{c}0.142 \\
(0.125)\end{array}$ & $\begin{array}{c}0.076 \\
(0.179)\end{array}$ & $\begin{array}{c}0.090 \\
(0.198)\end{array}$ & $\begin{array}{c}0.105 \\
(0.142)\end{array}$ \\
\hline Agree & $\begin{array}{l}-0.032 \\
(0.164)\end{array}$ & $\begin{array}{c}0.046 \\
(0.102)\end{array}$ & $\begin{array}{l}0.194^{*} \\
(0.114)\end{array}$ & $\begin{array}{l}-0.018 \\
(0.161)\end{array}$ & $\begin{array}{c}0.278 \\
(0.180)\end{array}$ & $\begin{array}{c}0.117 \\
(0.124)\end{array}$ \\
\hline Strongly agree & $\begin{array}{c}0.059 \\
(0.166)\end{array}$ & $\begin{array}{c}0.098 \\
(0.103)\end{array}$ & $\begin{array}{c}0.074 \\
(0.117)\end{array}$ & $\begin{array}{c}0.093 \\
(0.168)\end{array}$ & $\begin{array}{c}0.148 \\
(0.176)\end{array}$ & $\begin{array}{c}0.174 \\
(0.126)\end{array}$ \\
\hline $\begin{array}{l}\text { Sector of operations } \\
\text { Reference: Manufacturing }\end{array}$ & & & & & & \\
\hline Service sector & $\begin{array}{c}-0.235^{* *} \\
(0.098)\end{array}$ & $\begin{array}{l}-0.073 \\
(0.057)\end{array}$ & $\begin{array}{c}0.080 \\
(0.063)\end{array}$ & $\begin{array}{c}0.059 \\
(0.093)\end{array}$ & $\begin{array}{c}0.002 \\
(0.089)\end{array}$ & $\begin{array}{l}-0.010 \\
(0.061)\end{array}$ \\
\hline Union recognition & $\begin{array}{c}0.125 \\
(0.087)\end{array}$ & $\begin{array}{l}-0.023 \\
(0.057)\end{array}$ & $\begin{array}{c}-0.183^{* * * *} \\
(0.059)\end{array}$ & $\begin{array}{l}-0.134 \\
(0.095)\end{array}$ & $\begin{array}{c}0.017 \\
(0.088)\end{array}$ & $\begin{array}{l}-0.047 \\
(0.061)\end{array}$ \\
\hline $\begin{array}{l}\text { Workforce skill level } \\
\text { Reference: Clerical/ } \\
\text { administrative }\end{array}$ & & & & & & \\
\hline Technical/Professional & $\begin{array}{c}0.152 \\
(0.138)\end{array}$ & $\begin{array}{c}0.125 \\
(0.082)\end{array}$ & $\begin{array}{c}0.099 \\
(0.086)\end{array}$ & $\begin{array}{c}0.135 \\
(0.129)\end{array}$ & $\begin{array}{l}0.293 * * \\
(0.133)\end{array}$ & $\begin{array}{c}-0.043 \\
(0.090)\end{array}$ \\
\hline Sales staff & $\begin{array}{c}0.093 \\
(0.142)\end{array}$ & $\begin{array}{c}0.049 \\
(0.089)\end{array}$ & $\begin{array}{c}0.154^{*} \\
(0.092)\end{array}$ & $\begin{array}{c}0.059 \\
(0.142)\end{array}$ & $\begin{array}{c}0.047 \\
(0.131)\end{array}$ & $\begin{array}{c}0.024 \\
(0.092)\end{array}$ \\
\hline Manual operatives & $\begin{array}{c}0.109 \\
(0.133)\end{array}$ & $\begin{array}{c}0.057 \\
(0.082)\end{array}$ & $\begin{array}{c}-0.069 \\
(0.094)\end{array}$ & $\begin{array}{c}-0.096 \\
(0.137)\end{array}$ & $\begin{array}{c}0.172 \\
(0.130)\end{array}$ & $\begin{array}{c}-0.046 \\
(0.089)\end{array}$ \\
\hline Number of observations & 901 & 923 & 691 & 735 & 688 & 640 \\
\hline Goodness-of-fit ${ }^{b}$ & 0.099 & 0.109 & 0.145 & 0.159 & 0.243 & 0.176 \\
\hline
\end{tabular}

Notes: Robust standard errors in parentheses.

Not available for Canada

${ }^{b}$ Square of the correlation coefficient between the actual and fitted values of the dependent variable. It is interpreted in the same way as $\mathbf{R}^{2}$ in a linear model.

*Statistically significant at the .10 level; ** at the .05 level; *** at the .01 level (two-tailed tests).

\section{Tests of SSD}

Because system effects are to some extent measured as residuals after other effects have been taken into account, we begin at the most concrete level of societal effects before turning to dominance and system effects. We then consider whether SSD influences persist when organization-level variables are included. 


\section{Societal Effects}

The simplest view of societal effects is that differences exist by country of operation. Such differences are evident in Table 2: On five of the six sets of measures, there were significant differences among the four countries of operation. The effect sizes were greater than those in respect of the country of origin.

Yet the patterning of the differences is not consistent with societal effects of the kind expected in a neo-institutionalist or $\mathrm{VoC}$ approach. Using these approaches, we would expect Spain to be low on the use of HRM practices because the country is most distant from the sọurces of the practices. Low take-up should also be particularly marked in relațion to the LOG, and we might expect measures of control to be rare because the relevant practices are the hardest to implement in a CME with high levels of employment protection. In fact, the country stands out for high use of practices of a control kind. In particular, the assessment of managers against global competency measures was used in $91 \%$ of subsidiaries in Spain, compared to between $62 \%$ and $79 \%$ in Canada and Ireland, respectively; the use of variable pay was also relatively high. The country was not markedly different from the other three countries in terms of motivation or opportunity.

Our three LMEs also displayed differences from each other. It is true that, as Table 3 shows, MNCs in Ireland were not different from those in the United Kingdom on any of the measures, except for a small but significant difference in opportunity measures for the LOG, which were used more in the United Kingdom. Yet in Table 2 Canada stands out as having low use of opportunity measures. for both managers and the LOG and low use of control in relation to the LOG. The multivariate analysis reported in Table 3 confirms that these patterns were significantly different from those in the reference host country, the United Kingdom. When we looked at individual practices, we found that the use of variable pay was less common for both the LOG and managers in Canada than among the other countries. In relation to the LOG, for example, it was reported in $60 \%$ of subsidiaries in Canada, compared to $70 \%$ in Spain, $68 \%$ in the United Kingdom, and $67 \%$ in Ireland.

There is a specific explanation for the Canadian case. A natural aspect of the employment system to examine is the role of unions, because Canada has a North American system of detailed and legally enforceable collective bargaining. We found that the presence of a union had effects in Canada but not elsewhere. For example, variable pay and performance appraisal were much less common in Canada where a union was present: $52 \%$ of cases used performance appraisal, as against $92 \%$ of the nonunion firms. These effects were weaker in the other countries. That is, unions in Canada may have been able to limit the use of control and opportunity measures; it is also possible that motivation is used here as an alternative, though our data do not permit a close test of this. This result is one illustration of the consistency of our results with known specific features of national systems, in this 
case the distinctive role of unions, which do not always map onto LME-CME or institutional distance models.

\section{Dominance Effects}

To address dominance effects, we turn from the host country of a subsidiary to the country of origin of the MNC of which it is part. A strong expectation would be that there is a complete set of HRM practices that are most used by firms from the dominant economy, the United States. This expectation was not met: as Table 2 shows, on two of the six measures there were no differences of this kind, and on one, opportunity for managers, firms from CME countries in fact scored the highest. A more precise expectation is extensive use of control in U.S. firms. As Table 2 shows, there was evidence of this. When we looked at the individual components of the index, we found that it was the use of forced distributions in appraisal schemes that marked U.S. firms. More than a third of these firms (37\%) used this practice in relation to the LOG, as against $20 \%$ of non-U.S. firms. Other aspects of contingent reward were widespread and not peculiar to U.S. firms. Variable pay, for example, was used in about two-thirds of firms in relation to the LOG, and in $90 \%$ for managers, regardless of country of origin. Also, as Table 2 shows, the size of the differences between MNCs from the United States and from other countries was not large. Moreover, firms from CME countries scored higher on several measures, with the lowest scores in the middle range of coordination (i.e., "LME others").

In relation to the multivariate models (Table 3 ), if dominance effects were overwhelming, the measure of origin in the United States would have strongly significant coefficients in all models, in particular those for control. This was not the case. The coefficient for U.S. origin was significant only in respect of the measure of opportunity for managers, and the effect for CME origin on this measure was identical in size. In other words, it is firms from the United States and from CME countries that differ from firms from other LMEs on this specific measure. But other effects were absent.

With respect to motivation, MNCs from CMEs used fewer practices than those from the reference category (LME other than United States). ${ }^{3}$ We did not find significant differences in motivation practices between United States and other LME origins. Regarding the opportunity dimension, our results confirm the descriptive analysis by showing that both U.S. MNCs and those from CMEs used significantly more practices (around 0.5 more, on average) than MNCs from LMEs other than the United States.

\footnotetext{
${ }^{3}$ The interpretation of the marginal effects in Table 3 is as follows: Consider the estimated effect for $\mathrm{CME}$ in the motivation dimension for managers $(-0.511)$. This figure implies that, other things being equal, the average number of practices used by MNCs from CMEs is 0.5 points lower than the average number of practices used by the reference category (MNCs from LMEs other than United States). Although it could seem a very low difference, we should take into account that the range of the dependent variable is $0-4$. The effect is significant. The interpretation for the other estimated effects is analogous.
} 


\section{System Effects}

System effects are indicated by widespread use of HRM practices. The raw scores of the six indices in Table 2 are all above the midpoint of the relevant scale, suggesting extensive take-up. Scores for managers and the LOG were also similar, a result confirmed when we looked at the individual practices on which we had specific measures for both groups. This latter result runs against the idea that practices among the LOG are particularly constrained by societal factors, and is consistent with the idea of a wide distribution of practices, as system effects arguments would predict.

System effects are also suggested when associations linked to dominance and societal effects are weak. It is true that nine of the twelve sets of associations are statistically significant, but the effect sizes (shown by the $\eta^{2}$ statistic in Table 2) are not large. To take one example from the individual measures in Table 1, the use of two-way communication for the LOG varied between $86 \%$ for the U.S. group and $80 \%$ for the CME group.

Results that are anomalous with respect to alternative explanations also indicate system effects. The clearest example of this in Table 2 is that, on five of the six measures, subsidiaries in Spain used more HRM practices than those in the other three countries. Some readings of both dominance and societal effects, notably those based in neo-institutional and $\mathrm{VoC}$ theorizing, expect the reverse.

In multivariate models, system effects can be seen only indirectly, as residuals after other influences have been taken into account. The rather small proportions of variance explained by the many variables in the models suggest that such effects may exist. This is clearly only indicative evidence, but it adds to the picture.

\section{Organizational Structures and Choice}

As for organizational contingencies, namely, interdependencies, standardization, organization structure and size, these features were associated with the use of HRM practices broadly as expected, though the effects were rather less consistent than a strong contingency explanation would suggest. Thus, more-integrated MNCs, specifically those subsidiaries supplying other parts of the MNC, used on average more HRM practices, especially for the opportunity measures for the LOG, and motivation and control measures for managers. There was no association, however, with the extent to which products were standardized. In terms of organizational structure, the results do not generally support an argument suggesting that MNCs with more elaborate structures use more HRM practices. A more complex structure seems to play an important role on opportunity measures. These results are consistent with a weaker contingency argument, which says that these effects are present but that wider system and dominance effects may tend to reduce their impact.

The use of HRM practices was also connected to firms' policy choices. There was a consistent tendency for the presence of an international HR committee to be associated with the use of more practices. The effect was 
significant in five of the six models in Table 3, the exception being control measures for the LOG. In general, however, we did not find significant effects of the presence of a global philosophy on HR matters.

Sector had only a limited impact. Motivation measures for the LOG were most common in manufacturing, but there were no other differences. This would be consistent with the idea of the global diffusion of practices across sectors.

The effects of union recognition in the country of operation might also be expected to have a constraining influence on the use of practices with respect to the LOG but not managers. This is consistent with our results. The one clear union effect we find is to lower the use of control measures for the LOG, which is consistent with what one might expect given unions' general antipathy toward individualized systems of performance management.

The composition of the workforce in terms of skills did not in general demonstrate significant effects. There were a couple of exceptions: Control measures for the LOG were more spread for sales staff; and opportunity measures for managers were used more for technical and professional employees.

Overall, our results show that the integration of the firm, the organizational structure and the presence of an international HR committee, as well as size, play an important role on the use of HRM practices. These effects do not, however, wash out those linked to system, societal and dominance influences. The SSD model, moreover, stresses that MNCs are active agents in the configuring of HR systems. Our results are consistent with that idea.

\section{Discussion}

The SSD expectation is that there will be a defined set of best HRM practices that are widely diffused and whose use is not constrained by societal effects or firm-specific factors. We found evidence of diffusion and also of rather weak constraints. It should also be noted that we lacked measures of abilities. This is a limitation of our study but a necessary one, given that measures of them are most appropriate at workplace level. It also has one implication, drawn to our attention by a reviewer: It may well be that in the area of abilities MNCs tend to follow global best practices, for example in relation to the development of skills. If this is so, system effects will be evident here; the fact that we have identified these effects in other areas provides a conservative test.

This did not mean, however, that there was extensive take-up of the whole set of HRM practices. This fact suggests that anything like a "transnational solution" (Bartlett and Ghoshal 1989), in the sense of a single set of best practices toward which MNCs are converging, remains rare. The results here thus support scholars such as Brewster et al. (2008), though we take a less stark view of what these results mean: All the international evidence points to limited take-up of HRM practices (Kaufman 2010), and it would be remarkable if MNCs had really adopted a specific model in large numbers. There may be no single set of best practices, but there is also widespread adoption of some specific practices.

We have built on the work of Pudelko and Harzing (2008) by offering some ways to distinguish system and dominance effects. The latter are 
indicated by distinctively U.S. practices, which we have found in relation to the control dimension of HRM practices, and this confirms other work in this vein (Ferner and Almond 2013). We have not, however, found clear evidence of diffusion to countries closest to the dominant one. In particular, MNCs in Canada had a distinctly non-U.S. pattern of practices.

Such results support the idea that societal effects continue to operate. But these effects are less clear than some scholars would expect. Our three LMEs had as many differences as similarities. Moreover, Spain, usually counted as a CME, had more HRM practices in some areas than did the three LMEs. This result is consistent with the results of Björkman et al. (2007): MNC subsidiaries may respond to the institutional environment of a country by deploying relatively large numbers of new practices. In the case of Spain, as we noted, there is evidence of the malleability of the institutional context, despite the country's possession of some CME features. It may also be that MNCs in Spain use HRM practices extensively as a way of escaping the constraints of employment protection legislation. Our results support this view in two respects: They fit the idea of the malleability of the Spanish system (Ferner et al. 2001), and they are also consistent with the wider idea of "beneficial constraints" (Streeck 1997). This is the notion that it is not necessarily the case that firms will find best solutions if left unregulated and that placing constraints on how they operate may force them to think about how they behave: Limiting the freedom to hire and fire, for example, may lead to more careful systems to recruit workers and to use their skills. It may be that Spanish firms have thought imaginatively about HRM practices because they cannot readily hire and fire. It is also noticeable, however, that they have been able to introduce practices of control: They have not been constrained in the very fact of using practices like variable pay, nor have they had to use other sorts of practices as an alternative.

As for the Canadian pattern, we have pointed out the role of trade unions as one key part of the institutional context. There is also some evidence that MNCs understand the differences between the U.S. and Canadian contexts and that they tailor their HR approaches accordingly (Bélanger and Trudeau 2007). Such evidence warrants further investigation. We have also found some evidence of the adoption of HRM practices being the greatest in MNCs from well-defined business systems, those that are either clearly LMEs or CMEs. It may be that it is consistency of context, and not its nature, that encourages firms to adopt the practices.

We have also found evidence suggesting that MNCs' own characteristics are important. Some structural features of firms affected the use of practices, and there were strong associations between the HR architecture and the deployment of the practices. Some of the features of global integration, however, were less important. More global integration did not necessarily mean greater use of the practices. The relationship between corporate structures and how human resources are managed is contingent on both societal and dominance effects, an area often under-theorized in MNC research. Teasing out the contingencies warrants further analysis. 
If we put these ideas together, we have to accept that, while organizational contingencies and societal factors are reasonably clear-cut, system and dominance effects are necessarily hard to disentangle. This is the central limitation of our study. A common pattern, which looks like a system effect, could be the result of the widespread adoption of practices from a dominant model. We do not see this as a problem for the SSD framework because it stresses the interplay of different forces. A set of practices such as lean production, for example, may have begun as a dominant idea and then become more systemic in nature, and understanding its nature and effects is assisted by considering the relevant linkages, as opposed to treating it either as a specifically Japanese practice or simply as some context-free approach that will have the same meaning and effects anywhere (Elger and Smith 2005). In the context of our study, MNCs draw their HRM practices from many places, and they assemble them in distinct configurations. Our goal has been to show that they do indeed engage in such assembly and that they are influenced in their actions by their own organizational contingencies, their embeddedness in countries of operation and of origin, and global models. We have thus been able to go beyond LME-CME stereotypes, ideas of institutional distance, and models of simple global best practice.

\section{Conclusions}

One reason for the popularity of the original version of $\mathrm{VoC}$ may be the clarity of its models. We have now seen, however, that more subtle views still render predictions that can be addressed quantitatively. Future quantitative work can test these predictions more exactly. The research team is extending the surveys to other countries, which will allow different relationships between system, dominance, and societal effects to be addressed. In doing so, the role of choice, in particular the influence of the HR architecture, merits attention. Our results also have implications for workplace-level studies. We had no measures of abilities, but workplace studies can measure them and could study their use by MNCs as compared to other types of firm. Case study research is also now in a position to make carefully designed studies to build on the quantitative results, for example by identifying different kinds of MNCs and examining the extent to which they consciously adopt global models, together with the processes that they use to identify and disseminate these models. The SSD framework is a flexible and powerful one, but it needs further empirical development. For example, saying that a practice is global means more than that it is very common: The statement also suggests that the practice fits in some sense capitalism as a system and that there are processes that diffuse it globally. Research might explore the nature of this fit and processes of diffusion. Just how do MNC managers identify practices that they wish to pursue? We have identified the importance of structures such as international HR policy committees. Case study research might look at what such committees do. This kind of research will be the stronger the more that it compares types of MNCs (for example, 
those that practice integration in specific ways), teases out the influence of global forces, and follows through the effects in different societal contexts.

A related research direction derives from an experimental feature of the survey. In the United Kingdom, Ireland, and Spain, we asked firms whether they had a "key group" of employees who were central to the firm's success; we were thinking, for example, of research scientists in a pharmaceuticals company. In the United Kingdom, for example, $80 \%$ of respondents identified such a group. Given that firms have them, these groups might be the focus for case studies around such questions as how far they are seen as a global resource for the firm and how far employment practices for this special group reflect distinct global requirements.

As for MNCs and actors who engage with them, the results caution against two sets of simple lessons but also sustain an equally simple but profound idea. The first simple lesson would be that of a universal global best practice. We have seen that firms, in fact, vary considerably in their HRM practices. The second lesson would be the fit to various societal and organizational contexts. We have seen that these contexts are important but far from determining. The simple idea follows the configurational approach to HRM, which is increasingly presented as a development from the best practices or the best fit view (Paauwe and Boselie 2007). This states that firms configure their practices in ways shaped but not determined by their contexts. They have considerable choice, and they need to think how they wish to configure their activities to meet basic requirements and also to contribute to competitive objectives. HR managers may have a more active role than is sometimes thought. By the same token, other actors may be able to influence them in their choices. 


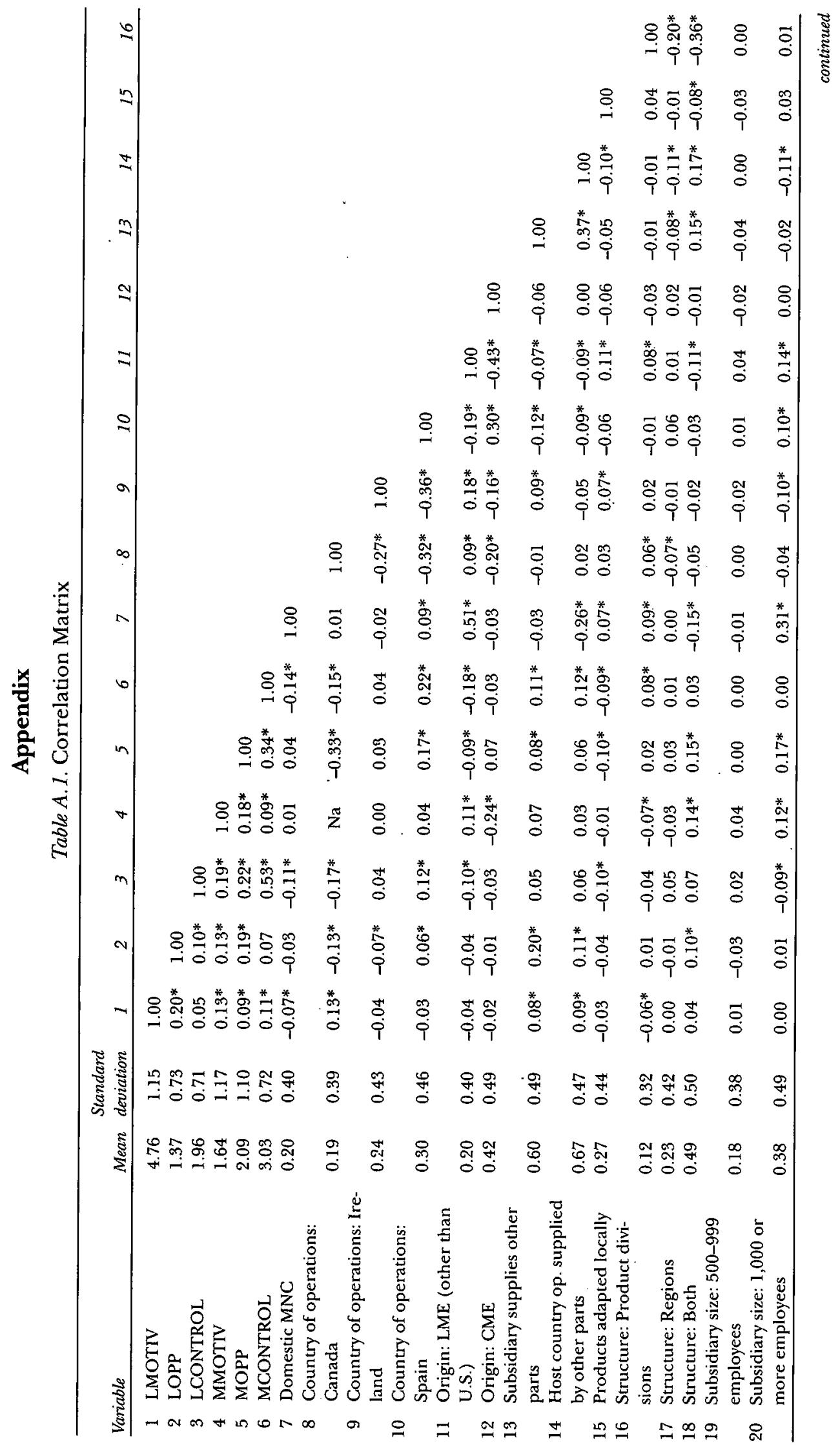




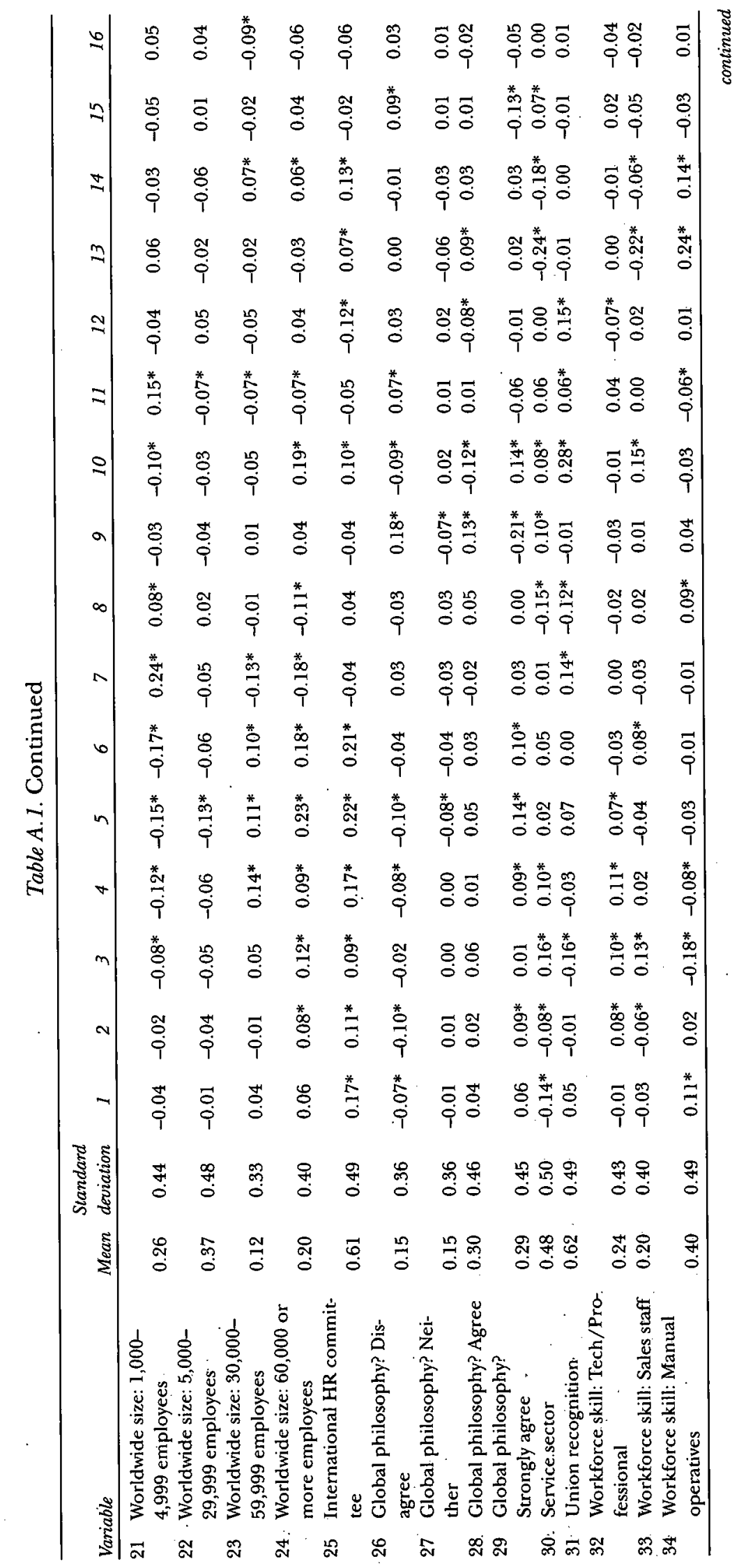




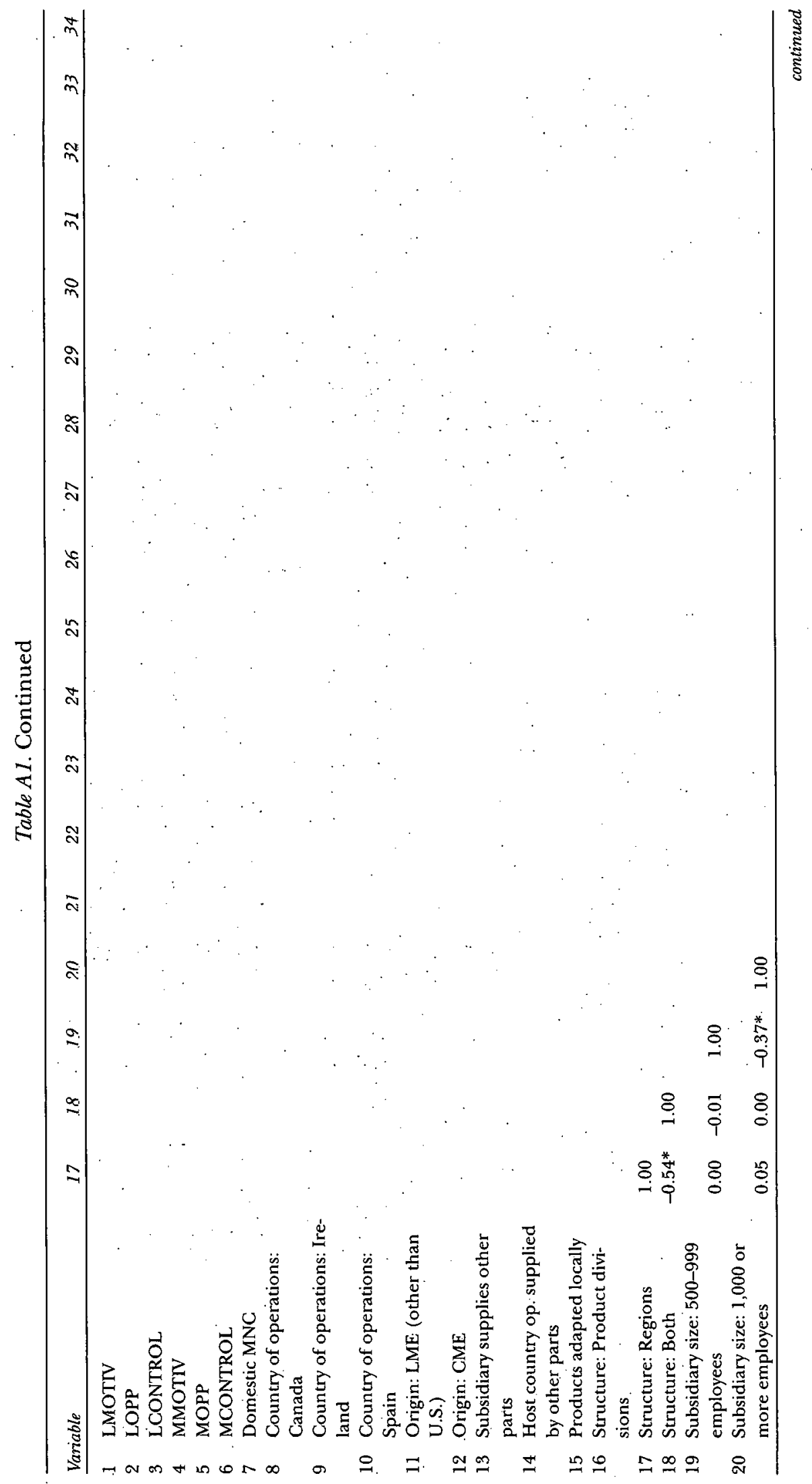




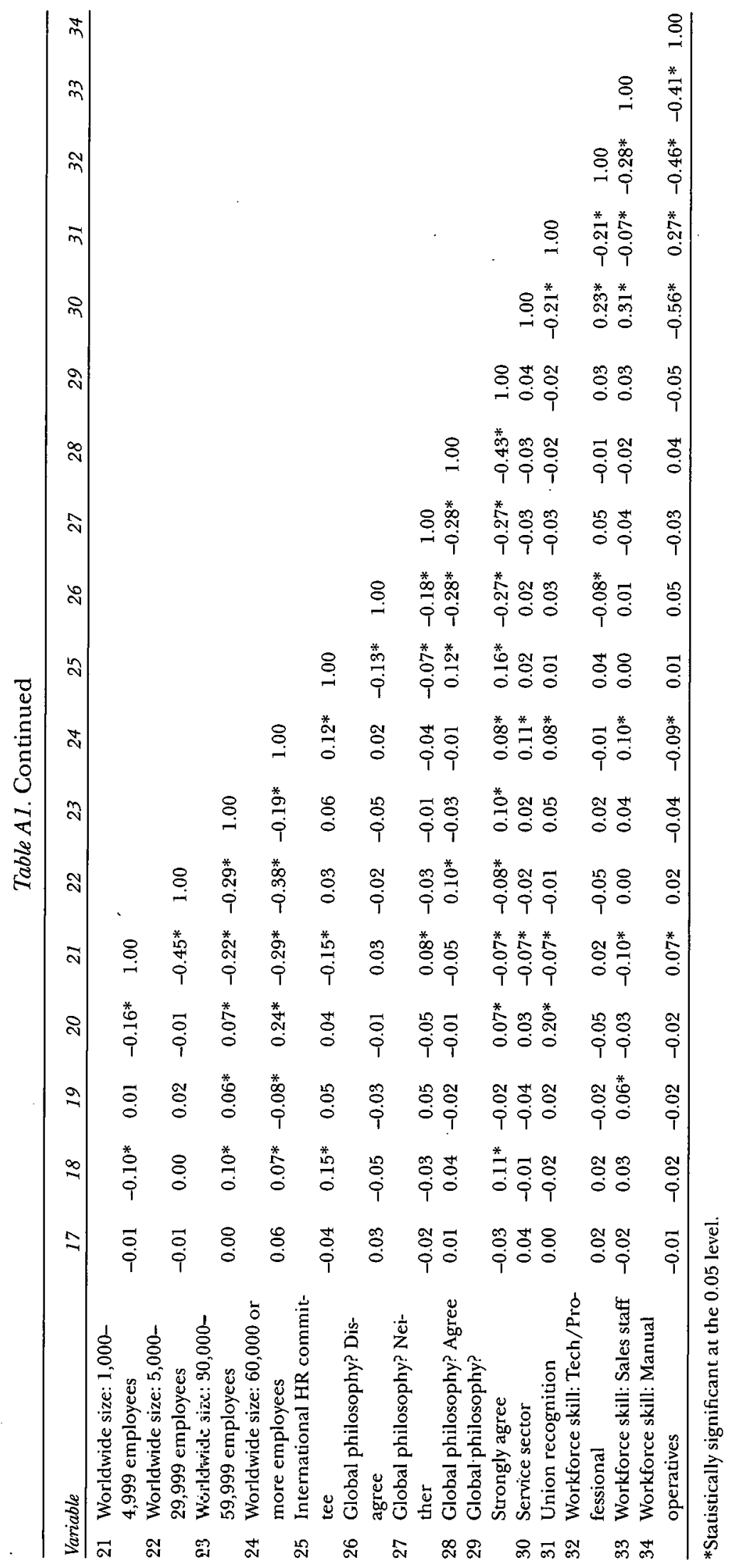




\section{References}

Almond, Phil, Tony Edwards, Trevor Colling, Anthony Ferner, Patrick Gunnigle, Michael Müller-Camen, Javier Quintanilla, and Helmut Wächter. 2005. Unraveling home and host country effects: An investigation of the HR policies of an American multinational in four European countries. Industrial Relations 44(3): 276-306.

Amable, Bruno. 2003. The Diversity of Modern Capitalism. Oxford: Oxford University Press.

Bartlett, Christopher A., and Sumantra Ghoshal. 1989. Managing across Boundaries: The Transnational Solution. Boston, MA: Harvard Business School Press.

Bayo-Moriones, Alberto, and Jose Enrique Galdon-Sanchez. 2010. Multinational companies and high-performance work practices in the Spanish manufacturing industry. Intermational Joumal of Human Resource Management 21 (8): 1248-71.

Becker, Brian, and Mark Huselid. 2006. Strategic HRM: Where do we go from here? Journal of Management 32(6): 898-925.

Bélanger, Jacques, and Gilles Trudeau. 2007. Le cadre réglementaire en matièred'emploi: L'industrie manufacturière québecoise en contexted integration économique. Relations Industrielles 62 (3): 433-65.

Björkman, Ingmar, Carl F. Foy, and Hyeon Jeong Park. 2007. Institutional theory and MNC subsidiary HRM practices: Evidence from a three-country study. Journal of International Business Studies 38(3): 430-46.

Boselie, Paul, Graham Dietz, and Corine Boon. 2005. Commonalities and contradictions in HRM and performance research. Human Resource Management Journal 15(3): 67-94.

Boxall, Peter, and John Purcell. 2003. Sirategy and Human Resource Management. Basingstoke: Palgrave.

Brewster, Chris, Geoffrey Wood, and Michael Brookes. 2008. Similarity, isomorphism or duality? Recent survey evidence on the human resource management policies of multinational corporations. British Joumal of Management 19(2): 320-42.

Bryson, Alex, Raphael Gomez, Tobias Kretchmer, and Paul Willman. 2007. The diffusion of workplace voice and high-commitment human resource management practices. Industrial and Corporate Change 16(3): 395-426.

Crouch, Colin. 1993. Industrial Relations and European State Traditions. Oxford: Oxford University Press.

. 2005. Capitalist Diversity and Change. Oxford: Oxford University Press.

Djelic, Marie-Laure. 1998. Exporting the American Model: The Postwar Transformation of European

Business. Oxford: Oxford University Press.

Dore, Ronald. 2008. Financialization and the global economy. Industrial and Corporate Change 17(6): 1097-1112.

Edwards, Richard. 1979. Contested Terrain. New York: Basic Books.

Elger, Tony, and Chris Smith. 2005. Assembling Work. Oxford: Oxford University Press.

Farndale, Elaine, Chris Brewster, and Erik Poutsma. 2008. Co-ordinated versus liberal market HRM: The impact of institutions on multinational firms. International Journal of Human Resource Management 19(11): 2004-23.

Ferner, Anthony. 2000. The underpinnings of 'bureaucratic' control systems: HRM in European Multinationals. Journal of Management Studies 37(4): 521-40.

Ferner, Anthony, and Phil Almond. 2013. Performance and reward practices in foreign multinationals in the UK. Human Resource Management Joumal. Forthcoming, doi: 10.1111/17488583.12001.

Ferner, Anthony, and Javier Quintanilla. 2002. Between globalization and capitalist variety. European Journal of Industrial Relations 8(2): 243-50.

Ferner, Anthony, Javier Quintanilla, and Matthias Z. Varul. 2001. Country-of-origin effects, host-country effects and the management of HR in multinationals: German companies in Britain and Spain. Joumal of World Business 36(2): 107-27.

Ferner, Anthony, Tony Edwards, and Anne Tempel. 2012. Power, institutions and the crossnational transfer of employment practices in multinationals. Human Relations 65(2): 16388.

Fligstein, Neil. 2001. The Architecture of Markets. Princeton: Princeton University Press. 
Fröbel, Folker, Jürgen Heinrich, and Otto Kreye. 1980. The New International Division of Labour. Cambridge: Cambridge University Press.

Hall, Peter A., and Daniel W. Gingerich. 2009. Varieties of capitalism and institutional complementarities in the political economy: An empirical analysis. British Joumal of Political Science 39(3): 449-82.

Hall, Peter A., and David Soskice. 2001. Varieties of Capitalism. Oxford: Oxford University Press.

Hancké, Bob, Martin Rhodes, and Mark Thatcher (Eds.). 2007. Beyond Varieties of Capitalism, pp. 3-38. Oxford: Oxford University Press.

Jacoby, Sanford. 1997. Modern Manors: Welfare Capitalism since the New Deal. Princeton, NJ: Princeton University Press.

Jones, Derek C., Panu Kalmi, and Antti Kauhanen. 2010. Teams, incentive pay and productive efficiency: Evidence from a food-processing plant. Industrial and Labor Relations Review 63(4): 606-26.

Kaufman, Bruce E. 2010. SHRM theory in the post-Huselid era: Why it is fundamentally misspecified. Industrial Relations 49(2): 286-313.

Keep, Ewart, Ken Mayhew, and Jonathan Payne. 2006. From skills revolution to productivity miracle. Oxford Review of Economic Policy 22 (4): 539-59.

Kochan, Thomas A., Russell D. Lansbury, and John Paul MacDuffie (Eds.). 1997. After Lean Production. Ithaca, NY: ILR Press/Cornell University Press.

Kostova, Tatiana. 1999. Transnational transfer of strategic organizational practices: A contextual perspective. Academy of Management Review 24(2): 308-24.

Kostova, Tatiana, Kendall Roth, and Marcus Dacin. 2008. Institutional theory in the study of MNCs: A critique and new directions. Academy of Management Review 33(4): 994-1007.

Lane, Christel. 1997. The governance of inter-firm relations in Britain and Germany. In Richard Whitley and Per Hull Kristensen (Eds.), Governance at Work, pp. 62-85. Oxford: Oxford University Press.

Lawler, John J., Shyh-jer Chen, Pei-Chuan Wu, Johngseok Bae, and Bing Bai. 2011. High performance work systems in foreign subsidiaries of American multinationals: An institutional model. Journal of International Business Studies 42 (2): 202-20.

Mayrhofer, Wolfgang, and Chris Brewster. 2005. European human resource management: Researching developments over time. Management Revue 16(1): 36-62.

McDonnell, Anthony, Patrick Gunnigle, and Jonathan Lavelle. 2010. Learning transfer in multinational companies: Explaining inter-organisation variation. Human Resource Management Journal 20(1): 23-43.

Meardi, Guglielmo, and András Tóth. 2006. Who is hybridising what? Insights on MNCs' employment practices in Central Europe. In Anthony Ferner, Javier Quintanilla, and Carlos Sánchez-Rundes (Eds.), Multinationals and the Construction of Transnational Practices, pp. 15583. London: Palgrave.

OECD [Organisation for Economic Cooperation and Development]. 2008. Employment protection index. Accessed at http://www.oecd.org/document/11/0,3746,en_2649_37457_ 42695243_1_1_1_37457,00.html (January 20, 2012).

Paauwe, Jaap, and Paul Boselie. 2007. HRM and societal embeddedness. In Peter Boxall, John Purcell, and Patrick Wright (Eds.), The Oxford Handbook of Human Resource Management, pp. 166-86. Oxford: Oxford University Press.

Parry, Emma, Michael Dickmann, and Michael Morley. 2008. North American MNCs and their HR policies in liberal and co-ordinated market economies. International Journal of Human Resource Management 19(11): 2024-40.

Pudelko, Markus, and Anne-Wil Harzing. 2007. Country-of-origin, localization or dominance effects? An empirical investigation of HRM practices in foreign subsidiaries. Human Resource Management 46(4): 535-59.

2008. The Golden Triangle for MNCs: Standardization towards headquarters practices, standardization towards global best practices and localization. Organizational Dynamics $37(4)$ : 394-404.

Sklair, Leslie. 2001. The Transnational Capitalist Class. Oxford: Blackwell.

Smith, Chris. 2008. Work organisation within a dynamic globalising context. In C. Smith, B. 
McSweeney, and R. Fitzgerald (Eds.), Remaking Management, pp. 25-60. Cambrịdge: Cambridge University Press.

Smith, Chris, and Peter Meiskins. 1995. System, society and dominance effects in crossnational organisational analysis. Work, Employment and Society 9(3): 241-67.

Stiglitz, Joseph E. 2002. Globalization and Its Discontents. New York: W. W. Norton.

Streeck, Wolfgang. 1997. Beneficial constraints. In Rogers Hollingsworth and Robert Boyer (Eds.), Contemporary Capitalism, pp. 197-219. Cambridge: Cambridge University Press.

Thelen, Kathleen. 2004. How Institutions Evolve: The Political Economy of Skills in Germany, Britain, the United States and Japan. Cambridge: Cambridge University Press.

Thompson, Paul, and Bill Harley. 2007. HRM and the worker: Labour process perspectives. In Peter Boxall, John Purcell, and Patrick Wright (Eds.), The Oxford Handbook of Human Resource Management, pp. 147-65. Oxford: Oxford University Press.

Tregaskis, Olga, Tony Edwards, Paul Edwards, Anthony Ferner, and Paul Marginson. 2010. Transnational learning structures in multinational firms: Organizational context and national embeddedness. Human Relations 63(4): 471-99.

Walsworth, Scott, and Anil Verma. 2007. Globalization, human resource practices and innovation: Recent evidence from the Canadian Work and Employment Survey. Industrial Relations 46(2): 222-40.

Whitley, Richard. 1999. Divergent Capitalisms. Oxford: Oxford University Press.

Wright, Patrick, and Wendy Boswell. 2002. Desegregating HRM: A review and synthesis of macro and micro HRM research. Journal of Management 28(3): 247-76. 
Copyright of Industrial \& Labor Relations Review is the property of Cornell University and its content may not be copied or emailed to multiple sites or posted to a listserv without the copyright holder's express written permission. However, users may print, download, or email articles for individual use. 